\begin{tabular}{|c|c|c|c|}
\hline 曲 & Received 01/03/2019 & $\sqrt{\overline{E \in}}$ & Published 12/04/2019 \\
\hline
\end{tabular}

\title{
Khaled Aboe El Fadl: Against Authoritarianism Teachers Talk To God
}

\author{
Parjiman \\ Email: parjiman@ilha.uad.ac.id
}

Universitas Ahmad Dahlan, Yogyakarta, Indonesia

ABSTRACT
A similar Qur'anic text with Allah Almighty as its creator is often Keywords
interpreted differently among Muslims. In the process of interpretation of
religious texts, the three elements, i.e., reader, text, and author are Khaled Abou El Fadl,
interrelated. Separating the three of them can give rise to otriarianism in
interpreting the meaning of the text, which is considered an act of
authoritarianism,
arbitrariness so that it is not uncommon for someone to assume the most reader, text, author,
correct interpretation. To avoid this attitude, according to Khaled Abou El negotiating process
Fadl, a negotiating process should be built between the three so that each
does not dominate in the process of determining the meaning of the text.
This paper is intended to describe the best relationship between the reader,
the text and the word of Allah in the theory of the negotiation of Khaled
Abou El Fadl.

\section{INTRODUCTION}

In the midst of the crisis and the collapse of the image of Islam on a global stage, which is partly dominated by violent extremism groups and prolonged bloody sectarian conflicts, "the presence of Indonesian Islam presented by Muhammadiyah and NU is able to become a new oasis and new qibla for the future of Islam in the world." To support this, Prof. Robert Hefner (Boston University), Prof. Greg Barton (Deakin University), and Scott Gilmore (University of Toronto) provide similar notes (Ma'arif in Azca, 2019: vi).

Despite the fact that Islam in Indonesia (including Muhammadiyah and NU) is far from being completely perfect, optimism is still permissible. In addition, as warned by a number of researchers such as Singh (2007) and Menchik (2018), Islam in Indonesia is surrounded by a wave of radicalism and intolerance that is not impossible to lead to the strengthening of what Singh calls 'Talibalization' or at least as the Menchik says the occurrence of 'Democratic breakdown'.

Currently the international world is experiencing a period of narrative and inspirative famine regarding a peaceful, democratic, and civilized style of Islam. In fact, to a certain extent, Islamic discourse on the regional and global scene is actually dominated by the discourse of violence, infidelity, 
liberalization, extremism and sectarianism carried out by a number of groups in the name of Islam, i.e., ISIS, a phenomenon in the Middle East and its 'branches' in the Middle East, all over the world that has claimed so many humanity victims. In the midst of the arid discourse of peaceful, democratic and civilized Islam, the humanitarian work that has been carried out by Muhammadiyah and Nahdlatul Ulama needs to get stronger and broader appreciation, especially in the arena of the international community (Ma'arif in Azca, 2019: ix).

Islam that is presented in a civilized manner by Muhammadiyah and NU is not enough if it is not followed by studies that answer the problem of why Muslims are left behind while communities from other religions are making progress. Efforts to study the leaps of thought such as those of Charles Sanders Peirce on Belief, Inquary and Meaning, Kim Knot on Insider-Outsider Perspectives, M. Abid Al Jabiri on the Bayani, Burhani and Irfan epistemology, Nidhal Guessoum on "Islam's Quantum Question: Reconciling Muslim Tradition, and Modern Science”, Abdul Karim Soroush on Reason, Freedom, and Democracy and Khaled Aboe El Fadl (Fadl, 2004) on Speaking in God's Name: Islamic Law, Authority, and Women are examples of content in a civilized Islam. The peace created will be meaningless if there are is no willingness to read, study, and duplicate the mind and practice to manage the development of science and technology in various nations that are now experiencing a glorious period.

\section{DISCUSSION}

\section{Problem of Islamic Law}

In his book "Speaking in God's Name: Islamic Law, Authority, and Women", Khaled Aboe El Fadl presents an anthropological or sociological study of the practice of Islamic law in modern time. He presents a conceptual framework for building ideas about authority and identifying abuse of authority in Islamic law. The focus of his study is on the idea of authority holders in Islamic law, as distinguished from authoritarianism. Through this book, he tries to explore ideas about how people represent the voice of God without considering themselves to be God, or at least, without wanting to be seen as God.

In the Induction section, Khaled Aboe El Fadl commences by quoting the Qur'anic verse: Wa mā ya'lamu junūda rabbika illā huwa, "No one can know the soldiers of God except God", (QS. Al Muddatstsir, 74: 31). In his opinion, this verse presents an interesting issue on interpretation (Fadl, 2014: 19).

He questions several things, i.e., Does it make sense that this question is raised to the reader if only God knows His soldiers? What should the readers understand from this statement? What does it mean that God knows what humans don't? Is it true that the readers must not try to investigate and identify his readings, or that the reader must not feel to be a soldier of God? According to Khaled Aboe El Fadl, the verse as an interpretation of this form of authoritarianism; the verse rejects the claim of humans as God's army that hold His authority (Fadl, 2014: 19). 
This understanding raises serious issues concerning the relationship between the reader, the text, and the text author. Amin Abdullah argues the relationship between the text, the writer or the author, and the reader in the dynamics of the struggle of Islamic law in particular and Islamic thought in general. More specifically, he emphasizes the actual mechanism for the formulation and decision making of fatwas issued by individuals, community leaders, and especially religious institutions and organizations in general (Abdullah in Fadl, 2004: viii).

Khaled Aboe El Fadl expresses his restless thoughts related to fatwas, particularly on women's matters, issued by the CRLO (Council for Scientific Research and Legal Opinions), an official institution in Saudi Arabia that is given the trust to issue fatwas. Islamic religious fatwas about women are considered by Khaled Aboe Al Fadl to be very problematic and demeaning to women (misogynistic traditions). Among the fatwas are: a) Prostrate to the husband and lick his ulcers, b) Keep the husband and God happy, and bring us to heaven, c) Crooked ribs, substandard intelligence, bad luck, dogs, and women, d) Prayers in the closet, close to the wall, and the danger of women's temptation, and e) Racism, sexism, and a sense of beauty.

Many CRLO legal experts emphasize a wife's obligation to obey her husband. This assertion is always attributed to the hadith that it is the wife's obligation to be obedient to her husband so that she bows down to him. Ibn al-Jahwi, a legal expert, makes an immoral claim that the wife must view herself for various practical reasons as her husband's slave. He states:

"A woman must know that she is the property of her husband, so she cannot take the initiative to do anything or use money without her husband's permission. She must prioritize her husband's rights over the rights of herself or her family, and she is ready to give satisfaction to her husband in various situations. A wife should not boast of her beauty in front of her husband, but should mention her husband's shortcomings; a wife must be patient with her husband's bad behavior, like the attitude shown by the attitude of a slave. Looking at the characteristics of the female slave described to Malik ibn Marwah when she was brought before him and said, "I do not forget who I am, I am your slave; thus, Malik answered, this slave woman is high in price" (Fadl, 2004: 308).

A wife is destined to live life as a loyal servant of her husband. If it is needed, she must serve the sexual needs of her husband on even a camel, and lick his ulcers that grow all over his body.

"Keep the husband and God happy, and bring us to heaven." To strengthen this statement that requires a wife to submit to her husband, CRLO and legal experts who agree with their opinions often quote traditions that are out of context, as does the piety of a wife. The literal text does not mention pious women, but only mentions that women who die and their husbands are pleased with them will go to heaven. This is as if hanging God's approval on the approval of the husband.

CRLO makes a decision that women must be set aside from the public sphere and all activities that indicate them in the public sphere. This decision is based on the hadith narrated by Abu Hurairah: 
"That the Prophet passed by before a group of women while greeting them. The Prophet said, $O$ women, increase your prayers, and multiply alms, because I see a lot that most of the inhabitants of hell are women. A wise woman said, "O Prophet, why are the inhabitants of hell mostly women?" The Prophet answered, "Because you often condemn and deny your husband's kindness. I have never seen anyone with a lack of reason and religion who can lead to a wise person besides you". Then, they said, "What is the lack of our reason and religion?" The Prophet replied, "Your lack of reason is that the testimonies of one man is equal to those of two women, and your lack in religion is that you spend your days without fasting and praying (because of the menstrual cycle)" (Siregar, 2016: 137).

In addition, another fatwa which is enough to make women as if they have no good or are always rotten and evil is the basis for most of the stipulations that regulate the appearance and behavior of women despite having covered their hair and body (hijab) according to the sharia. As a result, in the classic comments about the hadith, the following statements are found:

"Because God has predestined that men desire for women, and desire to look at women, women are
similar to the devil, in the sense that the tempter and men should not look at women and must avoid
them." Another source that also commented on the same hadith says that, "Some wise men say that
women are true evil, and the worst thing in them is that men cannot live without them. Women have
deficiencies in reason and religion, and they force men to do actions that are contrary to reason
and piety, such as the pleasure in the world and ignoring religious affairs, and that is a form of
decay that is very rotten" (Siregar, 2016: 138).

One example of history that claims that the Prophet once said, "Choose (a life partner) that is suitable for your children, but avoid (marry) black people because they are a race that is defective ( $f a$ innahu lawnun musyawwah)." Another narration claims that the Prophet said, "Black people live according to their genitals and stomach (meaning they like to commit adultery and eat). Furthermore, Ibn Hanbal says a history which states that "God created the white race from the right shoulder and the black race from the left shoulder." According to the scholars of hadith, the degree of authenticity of the traditions mentioned above varies, from the dha'if (weak) to hasan gharib (good). All of these are an ahad hadith (traditions narrated from a single transmission chain) which have not yet reached the degree of tawatur (traditions reported from several transmission chains). Misogynistic traditions will bring moral and social consequences as well as large normative consequences, so that in responding to these traditions, it takes a pause of accuracy, namely pausing to reflect on the position and impact of these traditions, and examine the extent to which the Prophet really played his role in the process authorship that gave birth to the hadith. This is specifically related to the narratives that demean women because of the patriarchal institutions which seem to have played an important role in the authorship process which gave birth to so many traditions (Siregar, 2016: 138-139).

These issues are of serious concern to Khaled Abou El Fadl, and make them a foothold in understanding how the real mechanism that must be done related to making conclusions and decisions about Islamic religious fatwas. In examining this, Khaled Abou El Fadl usesd an approach that M Amin Abdullah called hermeneutics (Abdullah in Fadl, 2004), to uncover and describe how an ideal relationship 
between the author, the text, and the reader could be. In reality, especially in today's modern context, as stated by Amin Abdullah, there is a strong tendency by religious people, especially Islam, to simply take over the author's authority, in this case the authority of the God, to justify absolute arbitrary action (despotism) carried out by the readers of religious texts. Here the process of change then takes place, that is, metamorphosis or the merging of readers and authors; in other words, the reader without regard to their inherent limitations becomes God (Author) that is without limits. The replacement or taking away of God's authority as an Author by the reader is an act of despotism and at the same time a form of corruption from the logic of Islamic law that cannot be justified.

\section{Building Authority Theory}

Khaled Abou El Fadl divided the term authority into two forms, i.e., coercive authority and persuasive authority. Coercive authority is the ability to direct the behavior of others by persuading, taking advantage, threatening, or punishing; therefore, reasonable people will conclude that for practical purposes they have no choice but to obey. Persuasive authority involves normative power. It is the ability to direct one's beliefs or behavior on the basis of trust. By quoting R.B. Friedman, Khaled distinguished between "being in authority" and "holding an authority". The first means occupying an official or structural position which gives the power to issue orders or directives. Someone who "holds authority" is obeyed by showing symbols of authority that give messages to others that they have the right to issue orders or directives. In contrast to "authority holders", here someone leaves his personal opinion because he is subject to authority holders who are seen to have better knowledge or understanding (Fadl, 2014: $50)$.

In terms of submission to authority, citing Friedman, Aboe El Fadl stressed that:

"... that is essential to the delineation of the distinctive kind of dependence on the will or the judgment of another person involved in an authority relationship. That is, the crucial contrast is between the case in which one man influences another to adopt some course of action by helping him to see the merits of that particular action and the case in which no reasons have to be given to a person to gain his compliance with a prescription because he "accepts" the person who prescribes it" (Fadl, 2014: 52).

“... submission to authority means the submission or transfer of individual decisions and reasoning. People who submit their decisions to others mean that they have given up their opportunity to test and assess the value of something they must believe or live. Such submission implies that a person surrenders his reasoning to the will and decisions of others, which is distinguished by efforts to understand the substantive value of the orders of the authorities which must be believed and carried out" (Fadl, 2004: 5).

As for authoritarianism in the Islamic context, Khaled Aboul Al Fadl explained: 
"In the Islamic context, I am convinced that authoritarianism is a behavior that does not adhere to the prerequisites of self-control and involves false claims whose impact is the abuse of God's Will. Authoritarianism is the neglect of God's ontological reality and the taking over of God's will by God's representatives so that the representative effectively refers to himself. In the movement of an authoritarian figure, the difference between the representative and his God becomes unclear and blurred. The statement of a representative and the will of his God are one and the same, because a representative grafts his determination into the command of his God. Because his God is represented by textual and non-textual instructions, in an authoritarian process, a representative, for practical purposes, denies the autonomy of these instructions and makes the sound of the signal entirely dependent on his own determination. The authoritarian dynamic of the person rejects the integrity of the text's instructions by expressing himself, and hinders the development and evolution of the meaning of the interpretive community" (Fadl, 2004: 6).

\section{Fight Authoritarianism}

Khaled Abou El Khaled used authority theory to construct the idea of authority holders in Islamic discourse. In constructing the concept of authority as a form of bridging the will of God, he raised three issues which play an important role in forming authority holders. These three are related to: 1) competence; authenticity; qualification test, 2) determination of meaning, and 3) representation (Fadl, 2004: 7).

In terms of competence, Al-Qur'an and Sunnah are the most convincing means for a Muslim to know God's will, because, in Islamic legal culture, both occupy the highest position as a means to find God's Will. In addition, there are also other means, such as reason, intuition, historical and natural studies, empirical facts that can be observed, consensus of pious people, and prayer and petition.

The qualification test referred to in this matter is the authority of the text to represent on behalf of or about God. For example, if it is proven to be sourced from God (God as the author) or from the Prophet, a text is then very qualified to represent on behalf of or about God. Likewise if a text is proven to originate from a Companion of the Prophet, it must also be questioned to what extent the text can represent on behalf of the Prophet, and finally in the name of God. Here, according to Khaled, we question, "What kind of competence does the source have to represent on behalf of or about God?" This question is related to media authenticity which conveys God's authoritative commands.

To analyze the issue of competence (text qualification test) is different between Qur'ans and As Sunnah (Al Hadith). The Qur'an is the eternal word of God and its purity is preserved; God is the author of the Qur'an and that the competence of the Qur'an is unquestionable. As far as the Qur'an is concerned, the only relevant issue is how to find its meaning. Meanwhile, the As Sunnah and other relevant historical material face very different challenges.

To analyze the problem of al-Sunnah competence, when related to the process of scientific epistemology, there is a long process that is historical in the bookkeeping of hadith. This process is often forgotten by Muslims due to the good intention to immediately practice what is read and carry out what is heard, so the process of the origin of the hadith is often overlooked. This condition is even more 
alarming when the rapid pace of science and technology and the fading away of the geographical-cultural barriers are not responded to with new attitudes and meanings.

The determination of meaning is an action to determine the meaning of a text. As long as God's commands rely on a text, they also rely on a language medium. Language is a vehicle that can be misleading. The letters, words, phrases and symbols give birth to ideas, images, and special emotions in a reader that can change over time. To some extent, language has an objective reality because its meaning cannot be determined separately by the author or reader alone. The text is only the closest approximation to the author's intent, especially since language itself is not permanent and changes forever. Language is semi-autonomous, adds its own rules and boundaries, and shapes and channels meaning (Fadl, 2004: 9). The meaning must be the result of interaction between the author, the text, and the reader, or what is called the negotiation process between the three parties; one party may not dominate the process of determining meaning. Starting with the principle of 'negotiation' between author, text, and reader, by making the text as a focal point and be open-minded, this emerged the 'negotiating hermeneutics' of Khaled Abou El Fadl (Fadl, 2014: 90).

His hermeneutics of negotiation is the process of searching for meaning which requires an interaction between text, author, and reader. According to him, these three elements must exist as a balance and must carry out a negotiation process. This is important to guarantee that there is no a more dominant party (Siregar, 2016: 133). Negotiations are needed to bridge the alienation in the time, region and socio-cultural distortion of the author with the text and the reader. Communicative dialogue occurs which is expected to be able to draw historical contextual analogies.

Negotiations on texts require the treatment of texts as old products that can be in a dialogue communicatively with auditions throughout history. This does not deny the existence of texts as historical products of the past. Negotiations are expected to give birth to meaning and the implication function. Interpretation functions to produce or re-create understanding that is owned by the text author and reader. This understanding will later have implications for the meaning of the text being interpreted (Siregar, 2016: 133).

Khaled Abou El Fadl uses the terms general representative (comment agent) and special representative (special agent) as a community of interpretations to analyze and differentiate authoritatively in Islamic legal discourse, specifically regarding the determination of meaning. The process of determining meaning will be problematic if the interpretation community positions itself as God's Representative. Regarding the special representative (God's Representative), in relation to understanding God's Will, Khaled Abou El Fadl explains that this special representative's authority is recognized only as long as he relies on the commands of his God. The commandments are not the only possible relationship with God. For example, a person might be able to develop a close and intimate relationship with God. The challenge is that such close and personal relationships cannot be accessed by others. Others can analyze textual evidence, but they may not be able to tell the results of their direct, 
personal, and contextual encounter with God (Fadl, 2004: 11). For this reason, in an effort to prevent and avoid religious organizations, groups and organizations from authoritarianism, Khaled Abou El Fadl proposes five preconditions: honesty, diligence, comprehensiveness, reasonableness, and self-retsraint.

Honesty is the attitude of not pretending to understand what he really does not know and being frank about the extent of knowledge and its ability to understand the will of God. Diligence is a hard and careful effort because it touches the rights of others, avoiding attitudes that harm the rights of others. Comprehensiveness is an attempt to investigate God's will thoroughly and consider all relevant texts. Reasonableness is an effort to interpret and analyze rational texts. Self-retsraint is a level of humility and self-control worthy of explaining God's will (Fadl, 2014: 142-143 and Siregar, 2016: 134).

\section{CONCLUSION}

In the process of understanding religious texts, reader, text, and author are the three elements that are interrelated. Separating between the three can lead to the attitude of authoritarian in understanding the meaning of the text. The attitude of authoritarianism is an act of arbitrariness in understanding the meaning of the text so that it is not uncommon to assume the most correct understanding. To avoid this attitude of authoritarianism, according to Khaled Abou El Fadl, a negotiating process should be built between the three (reader, text, and author) so that each does not dominate in the process of determining the meaning of the text. Determination of meaning comes from a complex, interactive, dynamic and dialectical process between the three elements (text, author, and reader). In addition, to prevent and avoid individuals, groups, and religious organizations from authoritarianism in determining the meaning of religious texts, Khaled Abou El Fadl also proposes five preconditions, i.e., honesty, diligence, comprehensiveness, reasonableness, and self-retsraint.

Islamic law is the result of the construction of the two highest authorities of Islamic teachings, i.e., the Qur'an and Hadith. Khaled Abou El Fadl offers a methodological framework in Islamic law with a Hermeneutic approach. This began with Khaled Abou El Fadl's worriness over the fatwas issued by the Council for Scientific Research and Legal Opinion (CRLO) in Saudi Arabia. This institution has the belief to issue fatwas, where they use misogynistic traditions as the highest authority to legitimize the validity of the fatwa they issue. These fatwas are considered authoritative and discriminatory, especially against women and appear to be rigid, unable to adjust to the demands of the times and conditions (Yoyo, 2018). This phenomenon of authoritarianism arises according to Khaled Abou El Fadl due to methodological errors in understanding the legal texts, not properly analyzing and considering important sources that are the basis for authority. This becomes a moral paradigm in interpreting sacred texts and for the sake of avoiding traps in interpreting authoritarianism. Khaled Abou El Fadl seeks to construct and integrate two treasures of classical and modern thoughts, especially in the field of hadith interpretation.

The hermeneutic approach used by Khaled Abou El Fadl is to claim that the most relevant and correct understanding is only the will of the author, so that the reader easily replaces the author's position 
and places himself or his institution as the only absolute possessor of truth authority. Consequently, there comes the process of metamorphosis or the integration of the reader and the author, in the sense that without caring about the limitations inherent in themselves and their institutions to become God (author) that has no limits. This situation leads to the emergence of authoritarianism and is opposed by Khaled Abou El Fadl.

The study of Islamic law by Khaled Abou El Fadl through a hermeneutic perspective is quite new, not only for Indonesian readers, but also for the Islamic world in general. Abou El Fadl's study of scientific and academic treasures is able to provide very in-depth knowledge about how to understand the text of the Qur'an as a non-criticism holy book and also contributes methods in the scientific realm by offering hermeneutic methods to understand the holy books and can be an analytical tool for scholars who take Islamic Studies.

\section{REFERENCES}

Al Qur'an dan Terjemahannya, Medinah: Khadim al-Haramain asy-Syarifain Raja Fahd, 1411.

Abou El Fadl, Khaled. Speaking in God's Name: Islamic Law, Authority, and Women, London: Oneworld Publications, 2014.

Agustina, Arifah Millati, "Peran Sosial Domistik Perempuan Dalam Tafsir Ibn Katsir: Sebuah Tinjauan Hermeneutik, AHKAM, Volume 4, Number 2, November 2016, pp. 349-362.

Azca, Muhammad Najib, et al., Dua Menyemai Damai: Peran Dan Kontribusi Muhammadiyah Dan Nahdlatul Ulama Dalam Perdamaian dan Demokrasi, Yogyakarta: Pusat Studi Keamanan dan Perdamaian Universitas Gadjah Mada, 2019.

Brown, L. Carl. "The Great Theft: Wrestling Islam from the Extremists by Khaled M.Abou El Fadl”, Foreign Affairs Magazine, March-April 2006.

D. A. Spellberg, "The Authoritative and Authoritarian in Islamic Discourses: A Contemporary Case Study by Khaled Abou El Fadl", Journal of Law and Religion, Volume 15, p. 397-398.

Ichwan, Moch Nur dan Ahmad Muttaqin (Ed.), Islam, Agama-agama, dan Nilai Kemanusiaan: Festschrift untuk M. Amin Abdullah, Yogyakarta: CISForm (Center for the Study of Islam and Social Transformation) UIN Sunan Kalijaga, 2013.

Imber, Colin. "Rebellion and Violence in Islamic Law Khaled Abou El Fadl", The American Historical Review, Volumer 109, Number 2 (April 2004), pp. 651-652.

Irawan, "Integrasi Sains Dan Agama: Suatu Tinjauan Epistemologi”, Tawshiyah, Volume 11, Number 1 (2016), pp. 124-149.

Kurnaengsih, "Konstruksi Syariah Dan Hak Asasi Manusia Terhadap Perempuan", Jurnal Risalah, Volume 1, Number 1 (December 2016), pp. 16-29.

Muttaqin, Labib. "Positifasi Hukum Islam dan Formalisasi Syari'ah Ditinjau dari Teori Otoritanisme Khaled Abou El Fadl”, Al-Ihkam, Volume 11, Number 1 (June 2016), pp. 67-92.

Muzammil, Iffah. "Peta Fiqh Muasir Muslim Progresif", ISLAMICA, Volume 7, Number 1 (September 2012), pp. 61-84.

Nurhakim, Imam. "Pertautan Antara Reader, Text, Dan Author Dalam Memahami Nash (Studi Hermeneutika Khaled M. Aboe El Fadl dalam Buku Speaking in God's Name: Islamic Law, Authority, and Women)", Maghza, Volume 2, Number 2 (July-December 2017), pp. 1-14.

Powers, David S. (Ed.), Islamic Law and Society, Volume 11, Number 1, Koninklijke Brill nv, Leiden, The Netherlands, 2004 
------. Islamic Law and Society, Volumer 18, Number 1, Koninklijke Brill nv, Leiden, The Netherlands, 2011.

Rachman, Budhy Munawar. Argumen Islam untuk Liberalisme, Jakarta: PT Grasindo, 2010.

-----, Islam dan Liberalisme, Jakarta: Friedrich Naumann Stiftung, 2011.

Rapoport, Yossef . "Rebellion and Violence in Islamic Law by Khaled Abou El Fadl", Middle Eastern Studies, Volume 39, Number 1 (January 2003), p. 207.

Rasyid, Idris. "Eksekusi 'Ab Intestato" Warisan Dua Banding Satu: Rasionalisasi Surah An-Nisa Ayat 11", Diktum: Jurnal Syariah dan Hukum, Volume 14, Number 2 (December 2016), pp. 201-213.

Rokhmatulloh, Nur. "Rekontruksi Mujtahid Klasik Menuju Mujtahid Kontemporer", al-Murabbi, Volume 1, Number 1 (2016), pp. 55-64.

Rumadi, "Fikih Hubungan Antarumat Beragama Di Indonesia: Fatwa NU, Muhammadiyah Dan MUI Tentang Relasi Muslim dan Non-Muslim”, Dialog, Volume 37, Number 1 (June 2014).

Rumadi dan Wiwit Rizka Fathurahman, Perempuan dalam Relasi Agama dan Negara, Jakarta: Komisi Nasional Anti Kekerasan terhadap Perempuan (Komnas Perempuan), 2010.

Sanaky, Hujair. "Gagasan Khaled Abou El Fadl Tentang Problem Otoritarianisme Tafsir Agama Pendekatan Hermeneutik Dalam Studi Fatwa-Fatwa Keagamaan", Al-Mawarid, Volume 14 (Edition XIV 2005), pp. 228-254.

Siregar, Lis Yulianti Syafrida. "Konstruksi Hermeneutika Dalam Studi Islam Tentang Hadis-hadis Misoginis (Studi Pemikiran Khaled Abou El Fadl)", TAZKIR: Jurnal Penelitian Ilmu-ilmu Sosial dan Keislaman, Volume 02, Number 2 (December 2016), pp. 123-142.

Shofan, Moh. "Islam Liberal: Menimbang Konteks, Merumuskan Penafsiran", Konfrontasi, Volume 4, Number 1 (January 2015), pp. 123-142.

Sikand, Yoginder. "Islam and the Challenge of Democracy by Khaled Abou El Fadl, JeremyWaldron, John L. Esposito and Noah Feldman, Economic and Political Weekly, Volumer 39, Number 25, Economic and Political Weekly, June 19-25, 2004.

Sukron, Mokhamad. “Kajian Hermeneutika Dalam 'Ulum Al-Qur'an”, Al-Bayan: Jurnal Studi Al-Qur'an dan Tafsir, Volume 1, Number 2 (December 2016), pp. 91-98.

Suryadi, "Rekonstruksi Kritik Sanad Dan Matan Dalam Studi Hadis", ESENSIA, Volume 16, Number 2 (October 2015), pp.

Syamsurijal, "Kekerasan Berbingkai Agama: Menelusuri Genealogi dan Perkembangan Fundamentalisme dalam Dunia Islam", AL-FIKR, Volume 20, Number 1 (2016),

Thahir, A. Halil. "Dari Nalar Literalis-Normatif Menuju Nalar Kontekstualis-Historis Dalam Studi Islam”, ISLAMICA, Volume 5, Number 1, September 2010.

Tujang, Bisri. "Hermeneutika Hadis Yusuf Qardhawi (Studi Analisa Terhadap Metodologi Interpretasi Qardhawi”, Al Majaalis Jurnal Dirasat Islamiyah, Volume 2, Number 1 (November 2014), pp. 33-68.

Yoyo. "Neo-patriarchy and the Problem of the Arab Crisis: A Critical Study on Hisham Sharabi's Works", QIJIS (Qudus International Journal of Islamic Studies), Volume 6, Number 2 (2018), pp. 251-268. 